\title{
REFERENCE MODEL OF BUSINESS INFORMATICS ECONOMICS MANAGEMENT
}

\author{
Milos MARYSKA ${ }^{1}$, Jaroslav WAGNER ${ }^{2}$ \\ ${ }^{1}$ Faculty of Informatics and Statistics, University of Economics Prague, \\ Nám.W.Churchilla 4, 13067 Prague 3, Czech Republic \\ ${ }^{2}$ Faculty of Finance and Accounting, University of Economics Prague, \\ Nám.W.Churchilla 4, 13067 Prague 3, Czech Republic \\ E-mails: ${ }^{1}$ milos.maryska@vse.cz (corresponding author); ${ }^{2}$ wagner@vse.cz
}

Received 13 September 2012; accepted 21 March 2013

\begin{abstract}
This paper is devoted to issues connected with processes that can be used for the management of economic efficiency of business informatics with the support in the area of Business Intelligence. We analyze the processes of the management of business informatics economics. We propose new model that takes into account requirements on the management of economic efficiency necessitated by accounting, managers of companies, differences in the method of accounting of business informatics cost and profits etc. Our model provides information that helps to define prices and costs for services provided by business informatics to other in-house units, provides information for cost analysis of each employee, total cost of each IS/ICT section, identifying the total costs of business informatics etc.
\end{abstract}

Keywords: business informatics, investment plan, economics, business intelligence, management, finance, model, IS/ICT, costs, profits.

JEL Classification: G31, M15.

\section{Introduction}

In the present economic situation with persisting apparent elements of the economic crisis, managers require, more than ever, exact information about the economic situation of their business (Aho 2012). They require good-quality information not only about the business as a whole but also about individual departments, divisions and activities, i.e. about business informatics as well. In order to evaluate the profit or loss of the activities connected with business informatics, i.e. in particular in information systems and information and communication technologies (IS/ICT), it is necessary to first identify the economic dimensions of such activities and to set up the procedures of measuring their efficiency.

If a business wants to be successful and competitive not only in the present but also in the future, it must accept and adequately respond to the trends in IS/ICT development 
and management that are shown e.g. in Vorisek (2008), Dragu, Tudor-Tiron (2013), Drost et al. (2011), Gregoire, Gough (2012).

The most important of them can be formulated as follows:

- It is necessary to obtain reliable, relevant and timely information.

- The IS/ICT of a business must be competitive on a global scale since market globalization brought new and large-scale competition that quickly overcomes geographic obstacles.

- IS/ICT must satisfy the needs of the management of individual businesses because of the growing demands of individual customers and the need to respond to their unique requests.

Research conducted in this area of business informatics economics management (Workie 2006; Mithas et al. 2012) confirms that businesses invest a considerable and ever-increasing sum of money in business informatics. The latest research conducted by the authors of this article in 2010 on a sample of 600 firms (Kunstova 2012, 2013) in the Czech Republic (CR), which were selected based on the structure of firms in the Czech economy, has also confirmed the increase in IT costs. According to Table $1,39.5 \%$ of the analyzed companies show an increase in the cost of business informatics and only $17 \%$ of the analyzed companies show a drop in the cost of business informatics.

Table 1. Trend in the cost of business informatics in analyzed companies

\begin{tabular}{ccc}
\hline Costs trend & Number of responses & Percentage of responses \\
\hline Decrease & 102 & $17.00 \%$ \\
\hline Without change & 261 & $43.50 \%$ \\
\hline Increase & 237 & $39.50 \%$ \\
\hline
\end{tabular}

Table 2 shows that small and medium-sized businesses had the highest increase in the cost of business informatics because, contrary to large businesses, they have less room for negotiations with their providers. However, in spite of this fact, $29 \%$ of the large businesses show an increase in the cost of business informatics as well.

Table 2. Trend in the cost of business informatics by company size

\begin{tabular}{cccc}
\hline Costs trend & $10-49$ employees & $50-249$ employees & $250+$ employees \\
\hline Decrease & $9 \%$ & $16 \%$ & $27 \%$ \\
\hline Without change & $39 \%$ & $44 \%$ & $44 \%$ \\
\hline Increase & $52 \%$ & $39 \%$ & $29 \%$ \\
\hline
\end{tabular}

These tables show that costs play a crucial role in business economics management since almost every managerial decision is based on a cost-effect comparison. This is certainly true about economics management and business informatics performance measuring as well. 
Under the pressure of economic trends connected with a detailed analysis of all investments, managers are now more and more interested not only in costs, which is typically the most important issue in economic analyses, but also in effects that IS/ICT investments bring to a business. Thus business informatics is gradually regarded not as a service of a standard required structure and quality where costs should be minimized but as one of the key main activities in the chain that creates the value of a business.

Effects can be identified through both proprietary procedures proposed based on the needs of a specific business and the application of prepared reference models adjusted to the characteristics of a specific business. A reference model is understood to mean a model created based on its creator's experience with business informatics management. It includes verified solution samples or variants and typical configurations for solving the individual parts of the business informatics management system.

In this case, the processes in reference models ensure the repeated measuring, analysis and comparison of the state and trend of business informatics economics in time. If these processes are set up correctly, we can e.g. analyze in detail the current situation of business informatics economics, plan their further development in a more effective and accurate way (Vorisek et al. 2004).

The latest trends in analyzing business economics and business economics management involve the use of Corporate Performance Management (CPM) as well as Business Intelligence (BI), which is part of CPM (Howard 2002). BI and CPM ensure the processing a large number of data with the goal to support the management of business economics, performance and processes. This is certainly true about the use of CPM and $\mathrm{BI}$ in the management of business informatics as well.

Many research conducted in the past decade (e.g. Novotny 2007; Maryska 2010; Parmenter 2007; Remenyi et al. 2007; Doucek 2011) show that business informatics economics management is a current and complicated problem because of the approach to business economics management and the measuring of business economics performance. The most important facts that lead to this conclusion are as follows:

- The link between business processes and their support by IS/ICT is not respected. IS/ICT is created and implemented based on a functional approach, and business informatics thus does not contribute to higher performance of processes or better results of a business.

- Investment decision-making of small businesses in particular can destabilize their economic situation (e.g. an investment that exceeds the financial possibilities of a business can threaten its existence) (Kivijarvi, Saarinen 1995).

- Businesses do not know the real cost of individual business informatics activities and lack the processes for tracking such cost. As a result, the cost of business informatics is insufficiently and inaccurately reflected in the performance of a business.

- Business informatics creates effects that, however, are not adequately and systematically monitored.

As a consequence, business informatics does not create expected effects and does not affect the performance of a business in a required way in spite of a large sum of money 
invested in business informatics. The basic problem of the current models and procedures of business informatics economics management is the absence of important characteristics that include especially the principle of multidimensionality and system integration with the processes of management of economics of other business activities. These facts determine the basic questions that the Reference Model of Business Informatics Economics Management (hereinafter referred to as the RME), which is proposed and introduced in this article, tries to solve:

- Is it possible to describe the relationship of costs to business informatics by processes? Can it be described by attributes that we can use for a follow-up analysis of this relationship?

- What processes can we use to identify e.g. the cost and profit of realized and planned activities?

- Is it possible to describe business informatics economics management as a complex and interlinked process?

- How can we interlink the processes of business informatics economics management with the processes of economics management of a business? What is their relationship?

- Should we use the existing reference models of business informatics economics management?

\section{Problem formulation}

For this article we chose only some of the mentioned problematic areas.

The goal of this article is to introduce the RME, its basic components and its link to the existing methodologies and to identify the areas where the RME expands and complements them.

An important part is the proposed procedure of RME implementation in a business and the verification of RME functionality. The central point of departure of the RME is the creation of a comprehensive map of logically follow-up sub-processes that are connected with the process of business informatics economics management. Such a created framework is then completed with methods and procedures for solving specific economic tasks of a business.

\section{Problem solution in the world and the $C R$}

\subsection{Analysis and synthesis of existing methodologies}

The first stage of the analytical proposal of the RME solution was based on an analysis and synthesis of information from information sources focusing on informatics and non-informatics. We started with the premise that the existing models and procedures include Best Practices (BP), i.e. the best procedures and experience, which we could use for the proposal and expansion of the complex RME. We had to modify and adjust individual BP to the needs of the RME (its processes, dimensions and indicators) in the economic and legislative system of the CR. 
In world literature there are several methodologies that help to manage business informatics economics through proposed suitable processes, metrics and indicators, processes, roles, approval matrices, etc. These internationally recognized methodologies can be exemplified by CobiT, Value IT and ITIL. More narrowly specialized is the approach of the company Gartner (Gartner 1) called Total Cost of Ownership (TCO). This approach resolves the problems with an insufficiently accurate identification of total, i.e. direct and indirect, cost of IS/ICT. However, it is complicated to use this approach since its basic calculation mechanisms are not available to the public.

We can say that in this area, world literature insufficiently reflects the economic and legal characteristics of countries, such as the CR, as well as the current trend of applying the principles of business performance management. In spite of this shortcoming, the most important publications in this area are e.g. Remenyi et al. (2007), Varian (2004), SEI_CMU (2009), ISACA (2007), ITIL (2007), Murphy (2002), Parmenter (2007), Gartner 1, Valanciene and Gimzauskiene (2009).

A detailed analysis of individual areas of business informatics economics management shows that there are actually many information sources for measuring the performance (efficiency) of business informatics. Some of the interesting publications are Gartner 1; Murphy (2002), Parmenter (2007), Remenyi et al. (2007), Varian (2004), Wade and Recardo (2001), Novotny et al. (2010).

Economics management both in and outside business informatics is connected with business processes. The topic of processes, including their setting and importance for business informatics management, is discussed in a comprehensive way e.g. in ISACA (2007), ITIL (2007). Even these information sources represent only a partial solution of this issue.

Another group of information sources, which essentially affects business informatics economics management, comprises of the trends connected with the development of accounting and accounting standards. Information sources covering this area are of general nature and do not discuss the specifics of business informatics, but are essential for the setting of information support processes and procedures for business informatics economics management. They are e.g. GAAP (2008), IFRS (2005), Atkinson et al. (2000), Wagner (2011).

The last group of information sources comprises of comprehensive methods that were developed to evaluate business performance. They are e.g. Beaver (1967), Kaplan and Norton (2000) and other.

The importance of this issue is obvious from different researches conducted by Czech and foreign academic institutions. Abroad business informatics economics management is researched e.g. at the Carnegie Mellon Software Engineering Institute (SEI_CMU 2009), University of California, Berkeley, and Cambridge University (Varian 2004). In the CR, this issue is researched e.g. at the Faculty of Informatics and Statistics of the University of Economics in Prague (Novotny 2007; Vorisek 2008) as well as e.g. at the Czech Technical University in Prague and other. 
The importance of measuring, managing and solving business informatics economics is also obvious from the interest of private companies in the provision of these services. We could mention e.g. the company Ernst and Young (EY 1), Gartner (Gartner 2) and IDC (IDC 1).

We divided the analyzed and applied information sources into the following comprehensive areas:

- Methodology of measuring, evaluating and managing business informatics economics ITIL (ITIL 2007), CobiT (ISACA 2007), Val IT (ISACA 2010), TCO (Gartner 1) etc.;

- Reference Model of Business Informatics Management (Vorisek 2008; Novotny 2007);

- Information sources focusing on the economic management of businesses and on business performance measuring e.g. CPM (Wade, Recardo 2001) and Value-Based Management (VBM) (Koller 1994; Favaro 2003);

- Information sources focusing on managerial accounting and cost management and forecasting (Atkinson et al. 2000; Kral 2010).

By analyzing the aforesaid information sources, we found out the following:

- ITIL, CobiT, Val IT and TCO methodologies include the basic procedures, processes and instructions, or part thereof, for business informatics economics management;

- None of the methodologies, except for the Reference Model of Business Informatics Management (ITGPM), include the multidimensionality principles and are ready for the application of $\mathrm{BI}$ and $\mathrm{CPM}$;

- None of the aforesaid methodologies, models and information sources (except for the ITGPM) (Kral 2010) have any link to the specific legislative and economic system of the CR;

- It is difficult to apply the general methodologies CPM and VBM, which focus on business performance management, to business informatics economics management since the nature of this type of management is very specific; it is highly demanding on economic resources and essential for the support of main business processes and yet its effects are evident only in the context of other business processes.

Based on these findings, we can say that the aforesaid information sources can be used, although with major modifications, for a wider definition of processes in business informatics economics management. Thus these methodologies can be used as an input for the proposal of the RME.

\subsection{Reference model of business informatics management (ITGPM)}

In compliance with the goal of this article, we shall introduce the ITGPM, into which the RME proposal is incorporated.

The theoretic framework of the ITGPM was created already in the year of 1995 in order to capture the structure of business IS/ICT. Due to the quickly developing complexity and heterogeneity of information systems as well as the growing pressure on the financial efficiency of business informatics management, the model was revised in 2000-2001 and expanded for business informatics processes and services. In Novotny's 
dissertation (Novotny 2003), the ITGPM was expanded for measuring processes and a list of more than 600 indicators that can be used to measure and subsequently manage business informatics.

The ITGPM principles and domains have been verified since 1995 by implementations in several dozens of companies.

The ITGPM consists of 10 parts (so-called domains) that are shown on Figure 1. The ITGPM includes dozens of generalized management processes that are divided based on different points of view, such as management level (strategic, tactical and operational), the role of business information specialists and users as well as indicators (metrics, indicators) for managing and analyzing business informatics, including relevant dimensions.

The ITGPM is very complex and we shall now focus only on one of its domains Financial management (FM). We shall thus discuss the Reference Model of Business Informatics Economics Management (RME). It is a component of the ITGPM, which is fully integrated as part of the FM domain. The purpose and goal of the RME is to provide a complex view of business informatics economics management as well as of possible procedures and approaches to this management. The RME can be implemented in a company either separately or as part of the entire ITGPM.

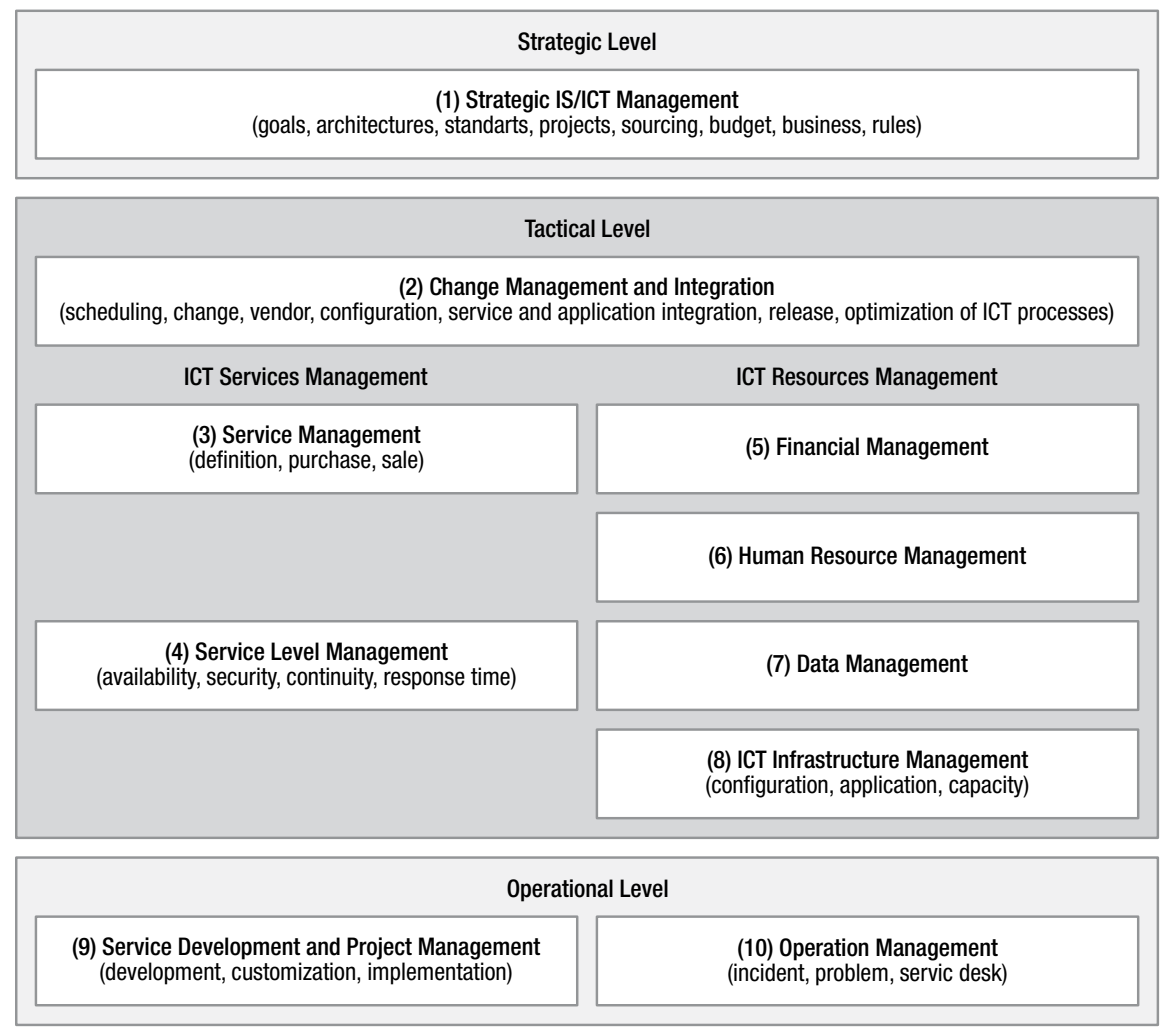

Fig. 1. Reference model of business informatics management (Novotny 2003) 


\subsection{Processes, dimensions and indicators of business informatics economics management}

Prior to starting the proposed new solution, i.e. the activities regarding the modification and expansion of the already existing processes of business informatics economics management, we specified in detail the individual parts of the RME.

\section{Processes in business informatics economics management}

We divided the processes, which we identified in business informatics economics management and specified as the fundamental part of the proposed RME, into two levels. The first level is represented by the master process, which consists of second-level processes (sub-processes). We called the master process - IS/ICT Economic and Financial Management. The sub-processes are as follows:

- Analysis of IS/ICT costs;

- Analysis of financial requirements;

- Analysis of financial resources for IS/ICT;

- Analysis of planned and executed effects (benefits) created by IS/ICT;

- Planned IS/ICT effects;

- Planned IS/ICT costs;

- Preparation of an IS/ICT investment plan;

- Preparation of an IS/ICT budget;

- Proposal of procurement of financial resources for IS/ICT.

We defined the basic characteristics of each sub-process, such as data inputs, the procedure of solving individual activities, the sequence of individual activities in a subprocess, cooperating sub-processes, outputs and the roles involved in the life cycle of a sub-process. The mutual interaction and sequence of sub-processes in the master process of business informatics economics management are shown in Figure 3. This is the fundamental difference as compared to ITIL, CobiT and Val IT methodologies, whose processes are not so detailed and are not incorporated into a comprehensive allcompany process.

To utilize the support of BI, we proposed for each sub-process suitable dimensions, which represent an analytical point of view for the evaluation of monitored indicators, and indicators, which express numerical values from the point of view of different dimensions and allow a detailed data analysis (Maryska 2010).

\section{Dimensions in business informatics economics management}

Thanks to research in literature, consultations with the ICT managers of pilot companies and survey sampling among economic entities (see Kunstova 2012), we identified the dimensions that we consider relevant for business informatics economics management. We defined each dimension as to:

- Purpose, framework definition of contents and the link to business processes and management methods;

- Attributes of dimension elements and their characteristics of contents;

- Gross basic structure; there can be several structures depending on the purpose of utilization. 
During the analysis, we discovered that the borderline between individual groups of dimensions may not be very clear. For this reason, we placed the "borderline" dimensions in the group where they would be used the most. We divided the dimensions of IS/ICT economics management into the following groups:

- Basic business dimensions, i.e. dimensions regularly used in most business BI applications (e.g. time, providers, plan - actual, business goals, business processes, business departments, business customers etc.);

- Basic informatics dimensions (e.g. databases, projects, services, software, business informatics applications, technical means, etc.);

- Economic dimensions and performance dimensions (e.g. categories of effects, cost types, budget, financial and cost accounts).

The setting of dimensions is very important for the model since it determines the basic scope of analytical and planning applications. Detailed attention is paid to dimensions in Novotny et al. (2010).

\section{Indicators in business informatics economics management}

From the list of indicators proposed in Novotny (2003), we selected a set of indicators that corresponded with the needs of business informatics economics management and expanded this set for other indicators, based on an analysis of information sources and business requirements. In this case, our information sources were e.g. ITIL (2007), ISACA (2007), Kral (2010).

For each indicator, we defined in particular:

- Basic contents and purpose of use;

- Unit of measure;

- Dimension;

- List of other derived indicators that make sense in connection with the given indicator.

We then subdivided the indicators in connection with the dimensions and tasks that are being solved as part of the RME. Such indicators are e.g.:

- Cost of business informatics;

- Cost of business informatics activities;

- Share of the cost of business informatics on the total costs of a business;

- Investment cost of business informatics;

- Cost of the operation, maintenance and management of the IS/ICT;

- Revenues from business informatics services and products;

- Increase in revenues as compared to the prior time period;

- Total drop in costs and increase in savings as compared to the prior time period;

- Increase in the number of customers in the given time period as compared to the prior time period;

- Reduction in the running time of realization of contracts as compared to the prior time period.

We assigned the said indicators to individual dimensions, using matrices presented in Table 3. Detailed matrices of these relationships are shown in Novotny et al. (2010). 
Table 3. Matrix of mutual relationships between dimensions and indicators

\begin{tabular}{cccc}
\hline Costs trend & $10-49$ employees & $50-249$ employees & $250+$ employees \\
\hline Decrease & $9 \%$ & $16 \%$ & $27 \%$ \\
\hline Without change & $39 \%$ & $44 \%$ & $44 \%$ \\
\hline Increase & $52 \%$ & $39 \%$ & $29 \%$ \\
\hline
\end{tabular}

Identification of the methods of identifying and evaluating indicators in mutual relationships is an important part of the model. This part of the solution is described in detail in Maryska (2010). The proposed model includes the following procedures:

- Traditional and modern calculation methods (e.g. Activity Based Costing) with the goal to analyze the information about the cost of individual sub-processes, products and services, based on an analysis of activities and relationship quantities;

- Cost Benefit analyses with the goal to evaluate and compare the effects and costs of projects, products and services;

- Earned Value Management focusing on the monitoring and evaluation of basic economic parameters in project management, e.g. labor and time spent on a project and project costs, and analyzing some performance characteristics of a final product;

- Traditional methods of project evaluation, e.g. net present value, internal revenue percentage, return on investment and other.

\subsection{Verification of proposed processes}

In the third phase of the solution, we focused on the verification of the proposed and modified processes, dimensions and indicators. For this purpose, we created a pilot application and implemented it in the company Siemens IT Solutions and Services (Siemens), using the steps that we proposed in the methodology of implementing the RME in the target company, which was divided into the following six phases:

- Zero Phase - identification of reasons for implementing the RME in a company;

- Defined Requirements Phase - definition of project goals and framework, appointment of project team members, etc.;

- Analysis Phase - specification of business needs, multidimensional analysis, identification of suitable indicators, confrontation of proposals with a customer's guarantors, identification data sources, etc.;

- Proposal Phase - proposal of data warehouse structures, proposal of transformation functions for processing data from source systems, proposal of managerial reports and print-outs, etc.;

- Implementation Phase - actual implementation of the analysis in the target environment, i.e. identification of technologies, programming, etc.;

- Testing and Verification Phase - verification of RME outputs and confrontation with the project sponsor's requirements.

The implementation of the RME is discussed in detail in Maryska (2010).

We created the pilot application based on the analytical proposal of the RME solution made for the platform Microsoft SQL Server 2005 (MS SQL). In MS SQL, we prepared 
the database part of the pilot application as well as data pumps that allow transmitting data from input data sources to the data storage. Finally, we also used the MS SQL platform to create an analytical solution providing access to identified characteristics through presentation levels (Microsoft Excel, ProClarity and other).

We verified the accuracy of the proposal and implementation methodology by RME pilot implementation in the Siemens. Furthermore, we modified the data model in such a way so that it would correspond with the hierarchical structure and other characteristics of this company. Then we created an analytical level. This level contained both the appropriate dimensions for analyzing the indicators of business informatics economics management and the actual indicators corresponding with the needs of Siemens. The last step that we took as part of the pilot implementation was the proposal of a presentation level.

The basic modification and implementation steps are shown in Figure 2.

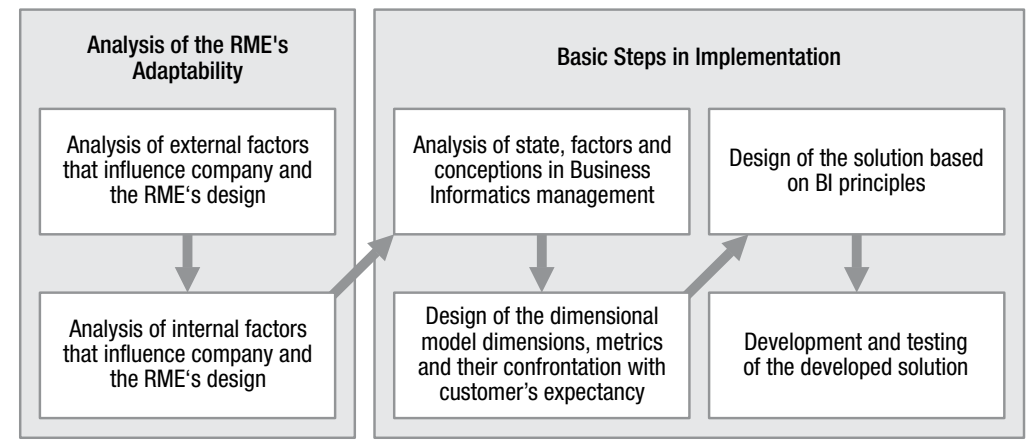

Fig. 2. Basic RME modification and implementation steps

\section{Results and discussions}

The utilization of the RME is connected with specific economic tasks in business management. In solving these tasks, the described sub-processes and systems of indicators connected with individual dimensions take the real economic content and help to ensure the required effectiveness of business informatics economics management.

We would like to point out that the basic principle of business informatics economics management is its continuity, which is ensured by the regular repetition of the subprocesses summarized in Figure 2. The frequency of their repetition always depends on the type of task that is being solved as well as on managers' requirements regarding the update of information provided and in particular the availability of updated data. The processes are designed in such a way so that they could be launched repeatedly.

The superior process shown in Figure 3 is launched automatically based on the set procedure. Its launch is followed by the processing of the specific task that is being solved. After the processing of the task in the sub-process is finished, the processing 
result returns as an input data source to the superior process, in which the solving of other tasks continues The process is carried out when all required activities and subprocesses of the RME were finished and their results correspond with the requirements set by the involved entities - e.g. company managers.

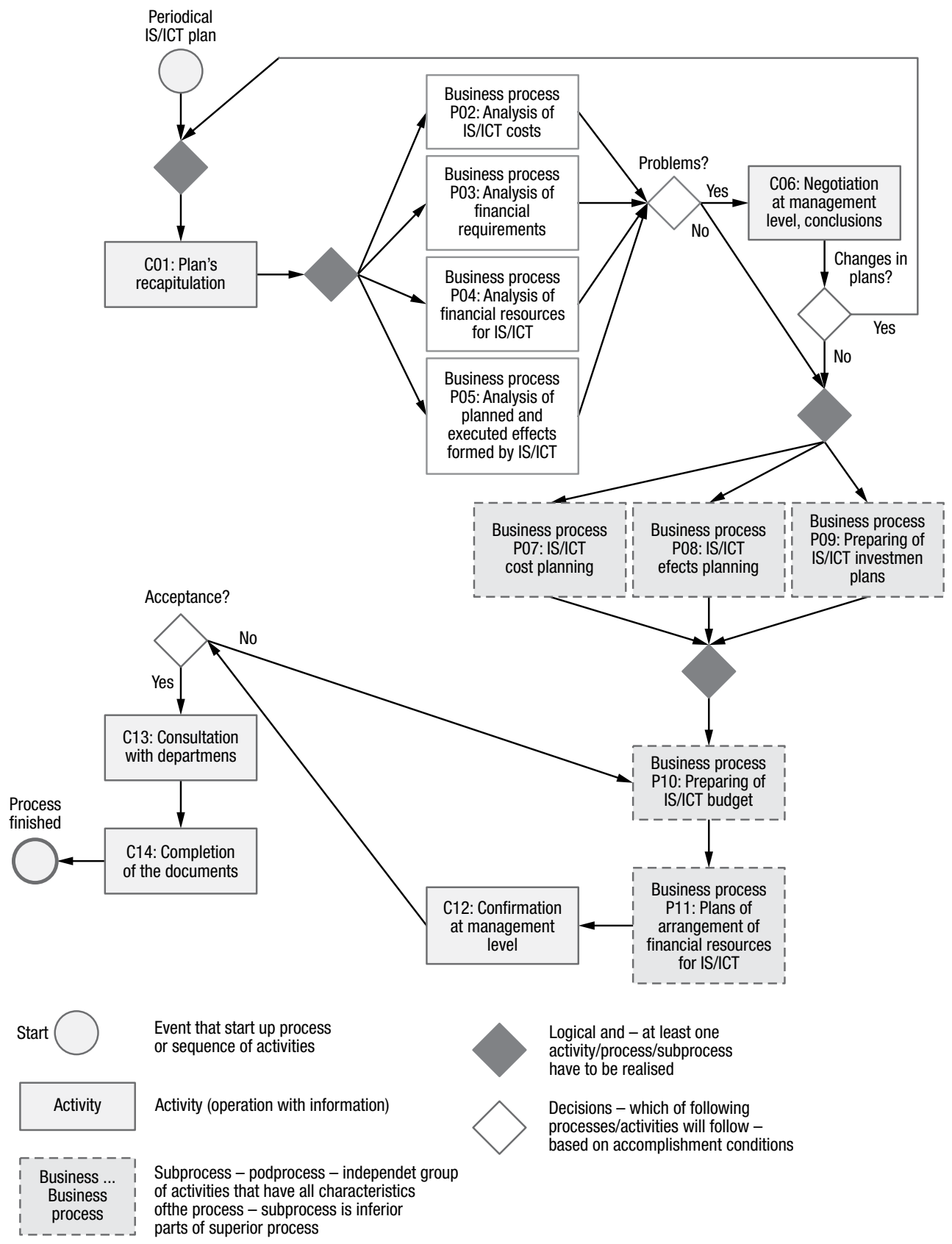

Fig. 3. Main process of business informatics economics management 
We have mentioned the use of BI in the proposed RME several times. The use of BI principles in business informatics economics management, the proposal of processes, measuring, etc. is important and makes sense because they especially help to:

- Create the tools supporting automated data transmission from in-house data sources to data warehouses;

- Create a system of indicators that makes possible to identify and analyze the actual economic situation and its trend and the performance and effectiveness of business informatics economics and a business;

- Compare the development of economics, performance etc. of business informatics in time and between businesses and identify any negative trends that require a timely response.

All this is important for the identification of exact economic results of both past and future activities in case of planning processes (we can compare with planning processes in public institution). However, the main thing is the technological and procedural support of the entire processing procedure. Nevertheless, in the context of this article, the presentation level, i.e. the interface toward its users, is the most important.

Our solution provides two types of presentation level:

- Static reports;

- Dynamic reports - analytical cubes.

Each type has its specific possibilities for its users.

Static reports provide their users with quick and easy access to automatic reports that contain pre-set indicators. These reports are generated every night based on current economic and other records in the data warehouse of solutions. Such generated reports are placed on the all-company portal that is accessible to designated company employees. These reports have their advantages and disadvantages. Quick and easy access to information is definitely one of their advantages. Their major disadvantage is their rigidness, i.e. it is not possible to change them in any way.

The second group - dynamic reports and analytical cubes - overcomes the disadvantages of the static reports while preserving their advantages. The major advantage of dynamic reports is that they make possible to generate ad-hoc reports and analyses. Nevertheless if these reports are generated online, it requires a longer time period between a report request and its generation. However, let's add that the data used for dynamic reports and analytical cubes are also generated on a daily basis just like in the case of static reports. To generate dynamic reports, we primarily used ProClarity and Microsoft Excel applications. 


\section{Conclusions}

IS/ICT economics management is a very significant activity among business activities and its importance keeps growing. It is a very important activity from the point of view of both business informatics managers and company managers.

Business informatics economics management cannot succeed without adequate procedures. If this type of management is not successful, i.e. business informatics does not show its importance for other business activities, the company top management cannot be expected to support it and to consider it one of the key departments keeping the entire business vital. If it is not possible to prove the benefits of business informatics, the company management shall see it as a simple cost item that should be minimized as much as possible.

The goal of the RME is to provide a comprehensive view of business informatics economics management. In the context of this goal, the RME provides planning and analytical functions of the management of economic aspects of business informatics. RME outputs can be used as basic data inputs for strategic decision-making, project planning, service contract drafting, etc.

In the RME, we proposed the process and sub-processes for business informatics economics management and expanded them for a proposal of dimensions and indicators that shall suggest to company managers how to manage business informatics economics, what characteristics to monitor and how to analyze them.

The proposed processes can be used not only as part of the RME but also separately since they identify the basic logical steps of the activities that must be performed in order to achieve the defined goal, e.g. to analyze IS/ICT costs, to prepare an IS/ICT investment plan, to prepare an IS/ICT budget, etc.

Unlike the existing reference models in this area, the RME provides a detailed approach to business informatics economics management especially thanks to the extensive use of BI principles. It provides recommended methods, processes, indicators, applications and examples of solving many specific tasks in business informatics management.

The proposed RME, including the methodology of its implementation, was verified by its implementation in the Siemens that joined the group of other large companies (E-On - South Czech, Czech Railways etc.), where the ITGPM model had been already implemented.

We can see the benefits of our model's implementation from the appreciation of the implementing company by stakeholders who positively evaluate the changes in corporate governance.

Based on our experience with the implementation and use of the pilot RME application in Siemens, we identified the problematic areas in the RME and the methodology of its implementation that we had to modify. These areas are as follows:

- Explanation of the basic goals of the model;

- Identification of primary source systems. 
Further research in this area should focus mainly on the following areas:

- Implementation of the proposed reference model in other companies;

- Detailed proposal of procedures to identify the effects, including specific reference examples of achieving this goal;

- Expansion of the number of dimensions suitable for analyzing economic indicators;

- Expansion of the set of indicators recommended for the evaluation of business informatics economics management and identification of the parameters, based on which we can select the indicators suitable for the company.

\section{Acknowledgement}

This article has been supported by the GACR through projects titled "P403/10/0092 Advanced Principles and Models of Managing Business Informatics" and "P403/11/1899 Sustainability support of SME based on ICT innovation”.

\section{References}

Aho, M. 2012. What is your PMI? A model for assessing the maturity of performance management in organizations, in PMA 2012 Conference, Cambridge.

Atkinson, A.; Banker, D.; Kaplan, S. 2000. Management accounting. Prentice Hall. ISBN: 9780132557610 .

Doucek, P. 2011. Human capital in ICT - competitiveness and innovation potential in ICT. Jindřichův Hradec 07.09.2011 - 09.09.2011, in IDIMT-2011. Linz: Trauner Verlag universitat, 11-22. ISBN 978-3-85499-873-0.

Dragu, I.; Tiron-Tudor, A. 2013. New corporate reporting trends. Analysis on the evolution of integrated reporting, in Annals of Faculty of Economics 1(1): 1221-1228 [online]. University of Oradea. Available from Internet: http://anale.steconomiceuoradea.ro/volume/2013/n1/129.pdf

Drost, R.; Harmsen, F.; Brinkkemper, S.; Versendaal, J. M.; Haanappel, S. 2011. A framework for IT performance management - enabling organizational growth with IT performance management. Utrecht: Utrecht University. ISSN UU-CS-2011-00.

Ernst and Young. (1). Technology risk: are your IT controls an asset or a liability? [Online], [cited 1 August 2010]. Available from Internet: http://www.ey.com/AU/en/Issues/Operationaleffectiveness/IT-effectiveness

Favaro, J. 2003. Value-based management and agile methods, in Proceedings of 4th International Conference on XP and Agile Methods, May, 2003, Genoa, Italy [online], [cited 18 May 2010]. Available from Internet: http:/www.favaro.net/john/home/publications/vbmams.pdf

Generally Accepted Accounting Principles in the United States (GAAP). 2008. [Online], [cited 5 October 2008]. Available from Internet: http://cpaclass.com/gaap/gaap-us-101.htm

Gartner. (1). 2009. Key Issues for Cost Optimization [online], [cited 1 August 2009]. Available from Internet: http://www.gartner.com/DisplayDocument?doc_cd=166713\&ref=g_economy

Gartner. (2). 2009. Gartner recommends 20 ways to cut IT costs [online], [cited 1 August 2009]. Available from Internet: http://www.networkworld.com/news/2008/101508-gartner.html

Gregoire, J.; Gough, M. 2012. Transforming cost allocation for information technology services - finding significant value in transparency [online], [cited 16 October 2013]. KPMG. Available from Internet: http://www.kpmginstitutes.com/shared-services-outsourcing-institute/ insights/2013/pdf/transforming-it-cost-allocation.pdf 
Howard, D. 2002. Corporate Performance Management Enhances BI [online], [cited 28 December 2008]. Available from Internet: http://www.gartner.com/resources/106700/106734/106734.pdf IDC. (1). IDC: companies going back to basics for costs savings and corporate governance [online], [cited 1 August 2009]. Available from Internet: http://www.searchsmbasia.com/en/content/ idc-companies-going-back-basics-costs-savings-and-corporate-governance

International Financial Reporting Standards (IFRS). 2005. International Accounting Standard Board.

ISACA. 2007. CobiT 4.1 Framework [online], [cited 29 July 2010]. Available from Internet: http://www.isaca.org

ISACA. 2010. Val IT 2.0 [online], [cited 29 July 2010]. Available from Internet: http://www. isaca.org

ITIL. 2007. ITIL: service strategy. TSO. ISBN 9780113310456.

Kaplan, R. S.; Norton, D. P. 2000. Balanced scorecard - strategický systém měrení výkonnosti podniku. Management Press. ISBN 8072610325.

Kivijarvi, H.; Saarinen, T. 1995. Investment in information systems and the financial performance of the firm, Information \& Management 28(2): 143-163. ISSN 03787206.

http://dx.doi.org/10.1016/0378-7206(95)94022-5

Kunstova, R. 2012. Process support of business and IT management in Czech companies, in Re-conceptualizing Enterprise Information System. LNBIP 105: 168-181. ISBN 3642288265.

http://dx.doi.org/10.1007/978-3-642-28827-2_12

Kunstova, R.; Potancok, M. 2013. How to measure benefits of non-standard healthcare systems, Inzinerine Ekonomika - Engineering Economics 24(2): 119-125. ISSN 1392-2785. Available from Internet: http://www.inzeko.ktu.lt/index.php/EE/article/view/2515/2464

Koller, T. 1994. What is Value-Based Management? Valuation: Measuring and Managing the Value of Companies, $2^{\text {nd }}$ [online], [cited 10 April 2009]. Available from Internet: http://www. exinfm.com/pdffiles/whba94.pdf

Kral, B. 2010. Manažerské účetnictví [Management accounting]. Management Press. ISBN 8072610627.

Maryska, M. 2010. Referenčni model ř́zeni ekonomiky podnikové informatiky. Doktorská disertační práce. VŠE.

Mithas, S.; Tafti, A.; Bardhan, I.; Goh, M. J. 2012. The impact of IT investments on profits, MIT Sloan Management Review, 20 March, 2012. ISSN 1532-9194.

Murphy, T. 2002. Achieving business value from technology. Wiley. ISBN 0471232300.

Novotny, O. 2003. Application of metrics in reference model of management of usiness informatics. Dissertation theses. Praha: VŠE.

Novotny, O. 2007. IS/ICT management reference model, in Revista de Engenharia de Computacao e Sistemas Digitais, vol. 3. ISSN 16788435.

Novotny, O.; Pour, J.; Maryska, M.; Basl, J. 2010. Řizeni výkonnosti podnikové informatiky. ProfPubl. ISBN 9788074310409.

Parmenter, D. 2007. Key performance indicators: developing, implementing, and using winning KPIs. Wiley. ISBN 9780470095881.

Remenyi, D.; Bannister, F.; Money, A. 2007. The effective measurement and management of ICT cost and benefits. Elsevier. ISBN 0750683287.

SEI_CMU. 2009. Software Results of SEI Independent Research and Development Projects [online], [cited 29 December 2009]. Engineering Institute. Available from Internet: http://www.sei. cmu.edu/library/abstracts/reports/08tr025.cfm 
Valanciene, L.; Gimzauskiene, E. 2009. Dimensions of performance measurement system in changes research, Inzinerine Ekonomika - Engineering Economics 4: 41-48. ISSN 1392-2785.

Varian, H. R.; Farrell, J.; Shapiro, C. 2004. The economics of information technology. University Press. ISBN 0521605210. http://dx.doi.org/10.1017/CBO9780511754166

Vorisek, J.; Pavelka, J.; Vít, M. 2004. Aplikační služby IS/ICT formou ASP [IS/ICT application services provided by way of ASP]. Grada. ISBN 8024706202.

Vorisek, J. 2008. Principy a modely řizení podnikové informatiky [Principles and models for management of business informatics]. Praha: Oeconomica. ISBN 8024514406.

Wade, D.; Recardo, R. 2001. Corporate performance management. Butterworth-Heinemann. ISBN 0877193860.

Wagner, J. 2011. Měření výkonnosti - vývojové trendy 2 poloviny 20 století [Developing tendencies of the second half of the 20th century], Politická ekonomie 6: 775-793. ISSN 00323233.

Workie, T. M. 2006. Návratnost' investícii do informačných technológií: empirické dôkazy z panelových dát krajín Európy [Return on investment in information technology: an empirical evidence of panel data in EU countries]. SAV. ISSN 00133035.

Milos MARYSKA. PhD works as a Senior Lecturer at the Department of Information Technologies at the University of Economics, Prague. He focuses on management of economics of business informatics, business intelligence and ERP systems. In the company Profinit works as a BI/CPM Consultant and Team Leader.

Jaroslav WAGNER. PhD graduated and PhD study at University of Economics in Prague. At present time he is Associated Professor at Department of Management Accounting at this university. He works as lecturer for many training institutions, namely Institute of Union of Accountants, Chamber of Auditors. He is a coauthor of several books and an author of papers concerning performance measurement and management accounting. 